The meteorological record for week ending November 7th, in Boston, was as follows, according to olservations furnished by Sergeant O. B. Cole of the United States Signal Corps: -

\begin{tabular}{|c|c|c|c|c|c|c|c|c|c|c|c|c|c|c|c|c|c|c|c|}
\hline \multirow{2}{*}{$\begin{array}{c}\text { Week ending } \\
\text { Saturday, } \\
\text { Nov. } 7,1885 .\end{array}$} & \multirow{2}{*}{ 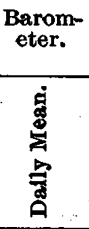 } & \multicolumn{3}{|c|}{ Thermometer. } & \multicolumn{4}{|c|}{$\begin{array}{c}\text { Relative } \\
\text { Humidity. }\end{array}$} & \multicolumn{3}{|c|}{$\begin{array}{l}\text { Direction of } \\
\text { Wind. }\end{array}$} & \multicolumn{3}{|c|}{$\begin{array}{l}\text { Velocity of } \\
\text { Wind. }\end{array}$} & \multicolumn{3}{|c|}{$\begin{array}{c}\text { State of } \\
\text { Weather.1 }\end{array}$} & \multicolumn{2}{|c|}{ Rainfall. } \\
\hline & & 总. & 嵒 & 兽 & $\begin{array}{l}\dot{1} \\
\dot{4} \\
\stackrel{8}{0}\end{array}$ & $\begin{array}{l}\dot{\theta} \\
\dot{\leftrightarrow} \\
\dot{8} \\
\dot{\varphi}\end{array}$ & 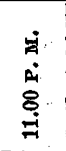 & 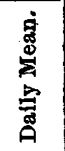 & $\begin{array}{l}\dot{8} \\
\dot{\alpha} \\
\dot{8}\end{array}$ & $\begin{array}{l}\dot{2} \\
\dot{0} \\
\stackrel{0}{0}\end{array}$ & $\begin{array}{l}\dot{z} \\
\dot{2} \\
\dot{0} \\
\dot{a}\end{array}$ & $\begin{array}{l}\dot{\Delta} \\
\dot{\Delta} \\
\dot{8}\end{array}$ & $\begin{array}{l}\dot{a} \\
\dot{\leftrightarrow} \\
\dot{8} \\
\dot{0}\end{array}$ & $\begin{array}{l}\dot{\Delta} \\
\dot{0} \\
\stackrel{8}{0} \\
\dot{1}\end{array}$ & $\begin{array}{l}\dot{a} \\
\dot{4} \\
8 \\
\end{array}$ & $\begin{array}{l}\dot{4} \\
\dot{1} \\
\dot{8} \\
\dot{\infty}\end{array}$ & $\begin{array}{l}\dot{\vec{g}} \\
\dot{\alpha} \\
\dot{8} \\
\dot{\theta}\end{array}$ & 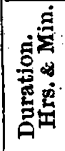 & 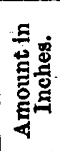 \\
\hline $\begin{array}{l}\text { Sunday,....1 } \\
\text { Monday,...2 } \\
\text { Tuesday,...3 } \\
\text { Wednes,, ..4 } \\
\text { Thursday, . } \\
\text { Friday, } ; 2.6 \\
\text { Saturday, }, .7\end{array}$ & $\begin{array}{l}30.310 \\
29.6 \times 3 \\
29.736 \\
229.984 \\
30.038 \\
\mathbf{3 0 . 1 0 9} \\
30.073\end{array}$ & $\begin{array}{l}37.2 \\
50.1 \\
42.7 \\
44.0 \\
86.3 \\
61.9 \\
54.5\end{array}$ & $\begin{array}{l}43.9 \\
58.1 \\
50.1 \\
49.0 \\
66.6 \\
60.1 \\
63.1\end{array}$ & \begin{tabular}{l|}
26.3 \\
42.8 \\
37.2 \\
38.8 \\
41.6 \\
49.0 \\
48.8
\end{tabular} & $\begin{array}{r}68.0 \\
93.0 \\
79.0 \\
71.0 \\
73.0 \\
90.0 \\
100.0\end{array}$ & $\begin{array}{l}71.0 \\
81.0 \\
57.0 \\
62.0 \\
63.0 \\
95.0 \\
100.0\end{array}$ & $\begin{array}{r}77.0 \\
74.0 \\
74.0 \\
72.0 \\
86.0 \\
100.0 \\
92.0\end{array}$ & $\begin{array}{l}72.0 \\
82.7 \\
70.0 \\
68.3 \\
74.0 \\
95.0 \\
97.3\end{array}$ & $\begin{array}{l}\text { N. } \\
\text { S.E. } \\
\mathbf{W} . \\
\mathbf{W} . \\
\text { s.w. } \\
\text { W. } \\
\text { N.E. }\end{array}$ & $\begin{array}{l}\text { S.E. } \\
\text { S.W. } \\
\text { N.W. } \\
\text { W. } \\
\text { s:W. } \\
\text { E. } \\
\text { E. }\end{array}$ & $\begin{array}{l}\text { S.E. } \\
\text { W. } \\
\text { w. } \\
\text { s.w. } \\
\text { s.w. } \\
\text { N.E. } \\
\text { s.w. }\end{array}$ & $\begin{array}{r}11 \\
133 \\
12 \\
14 \\
12 \\
4 \\
4\end{array}$ & $\begin{array}{r}12 \\
16 \\
20 \\
16 \\
11 \\
10 \\
3\end{array}$ & $\begin{array}{r}15 \\
15 \\
15 \\
3 \\
y \\
2 \\
9\end{array}$ & $\begin{array}{l}\text { C. } \\
\text { R. } \\
\text { C. } \\
\text { o. } \\
\text { o. } \\
\text { G. }\end{array}$ & $\begin{array}{l}\text { o. } \\
o . \\
\text { C. } \\
\text { C. } \\
\text { o. } \\
\text { G. } \\
\text { G. }\end{array}$ & $\begin{array}{l}\text { o. } \\
\text { C. } \\
\text { C. } \\
0 . \\
\text { o. } \\
\text { R. }\end{array}$ & $\begin{array}{l}\bar{z} \\
\bar{z} \\
\overline{=}\end{array}$ & $\begin{array}{l}\bar{z} \\
\bar{z} \\
1.23\end{array}$ \\
\hline $\begin{array}{l}\text { Mean, the } \\
\text { Week. }\end{array}$ & 29.947 & 47.1 & 55.8 & 40.7 & & & & 79.9 & & & & & & & & & & & \\
\hline
\end{tabular}

i O., cloudy ; C., clear ; F., fair ; G., fog ; H., hazy ; S., smoky ; R., rain ; T., threatening.

OFFICIAL LAT OF CHANGES IN THE STATIONS AND DUTIES OF OFFICERS SERVING IN THE MEDICAL DENOVEMBER 13, 1885.

BAIrys, E. I., surgeon and colonel. Relieved from duty as attending surgeon, San Francisco, Cal., and ordered for duty as medical director, Division of the Pacific and Department of California.

NORRIs; BAsIL, surgeon and lieutenant colonel. Ordered for duty as medical director, Department of the Columbia.

MCKeE, J. C., surgeon and major. Ordered for duty as attending surgeon and examiner of recruits, Boston, Mass.

Volsum, E. P., surgeon and lieutenant colonel. Ordered for duty as medical director, Department of Texas.

SMrTH, J. R., surgeon and lieutenant colonel. Ordered for duty as attending surgeon, New York City, N. Y.

ALEXandrR, R. H., surgeon and lieutenant colonel. Ordered for duty as medical director, Department of Arizona. S. O. 260, A. G. O., November, 11, 1885.

KANE, JoHN J., assistant surgeon and captain. Ordered for duty as post-surgeon, Fort Ringgold, Texas. S. 0 . 141, Depart ment of Texas, November 4, 1885 .

EBert, R. G., assistant surgeon and captain. Ordered from Camp Grant, Riverside Park, New York City, to Fort Hamilton, New York Harbor, for duty. S. O. 237, Department East, November 5,1885 .

BushnelL, G. E., assistant surgeon and first lieutenant. Assigned to duty at Camp Grant, Riverside Park, New. York City. S. 0. 237, Department East, November 5, 1885.

OFFIGIAL LIST OF CHANGES IN THE MEDICAL CORPS OF THE UNITED STATES NAVY DURING THE WEEK ENDED NOVEMBER 14, 1885 .

Sayre, J, S , assistant surgeon. Detached from Naval Hos pital, Mare Island, and ordered to the "Omaha."

Drxon, W. S., surgeon. Detached from coast survey steamer " Hassler," upon reporting of his relief, Past Assistant Surgeon D. $O$. Lewis, and wait orders.

LEwIs, D. ח., past assistant surgeon. Detached from naval rendezvous, San Francisco, and ordered to relieve W. S. Dixon, steamer "Hassler."

Dungan, J. S., medical director. Ordered to naval rendezvous, San Francisco, to relieve Yassed Assistant Surgeon D. O. Lewis.

OFFICIAL LIST OF CHANGES OF STATIONS AND DUTIES OF MEDICAL OFFICERS OF THE UNITED STATES MARINE-HOSPITAL SERVICE FOR THE WEEK ENDED NOVEMBER 7, 1885.

URQUHART, F. M., passed assistant surgeon. Upon the clos ure of the Cape Charles Quarantine Station to proceed to Norfolk, Va., for duty, November 5,1885 .

BatTLE, K. P., assistant surgeon. Resignation accepted, as tendered, by the Secretary of the Treasury, to take effect November 25,1885 , November 3,1885 .

\section{SOCIETY NOTICE.}

Norfolk District Medical Societr. - A meeting for Scientific Improvement will be held at Room 7, Palladio Hall Building, corner of Warren and Dudley Streets, Roxbury, on
Tuesday, November 24th, at 7.45 P.M. Communications: I. Exhibition of a New Dressing for Fracture of the Claviole, Edw. 'T. Williams, M.D. II. Arsenical Poisoning, Joseph Stedman, M.D. III. Multiple Neuritis, Robert Bell, M.D. Particular attention is called to the new place and time. A cordial invitation is extended to members of other Districts to be present at the meetings of the Norfolk District, and participate in its discussions. S. Alimen. Potter, M.D., Secretary.

RESOLUTIONS ON THE DEATH OF DR. JOSEPH $R$. DRAPER.

At a meeting of the South Boston Medical Club the following preamble and resolutions were adopted: -

Whereas, Death has removed from our midst our much esteemed friend and colleague, Dr. Joseph R. Draper, and whereas it is fitting that this Society, of which he was one of the founders and a former president, should express their feeling of sorrow at this great loss, therefore:

Resolved, that we gladly testify to our appreciation of his great professional skill, his readiness to advise when called upon by any of us, his honesty of principle toward his medieal brethren and toward his patients, his affability at our social gatherings, all of which we shall ever bold in grateful remembrance.

Resolved that the death of Dr. Draper is a loss to the community in which he lived and for which he worked so many years but that his loss will be felt more directly by his professional associates

Resolved, that a copy of these resolutions be put upon the reeords of this Society, a copy be forwarded to his afficted family, a copy be published in the S'outh Boston Inquirer and in the Boston Medical and Surgical Journal.

F. G. REED, Secretary.

DEATH.

Died in Leicester, Mass., November 12, 1885, George Otis Warner, M.D., M.M.S.S.

\section{BOOKS AND PAMPHLETS RECEIVED.}

Transactions of the South Carolina Medical Association Thirty-Fifth Annual Şession, held in Charleston, N. C., April $21-23,1885$.

Letters from a Mother to a Mother on the Formation, Growth and Care of the Teeth. By the Wife of a Deutist, "Mrs. M. W. J." Philadelphia: Welch Dental Co. 1885.

The Pedigree of Ilisease: being Six Lectures on Temperament Idiosyncrasy and Diathesis. Delivered in the Theatre of the Royal College of Surgeons in the Session of 1881, by Jonathan Hutchinson, F. R. S. New York: Wm. Woud \& Co. 1885. A Text-Book of Nursing. For the Use of Training Schools Families and Private Students. Compiled by Clara S. Wer New Xork: $\mathcal{D}$. Appleton \& Co. 1885.

A Practical Treatise on Diseases of the ": idneys an

Derangements. liy Charles Henry Ralfe, M.A.M.T

With Illustrations. Philadelphia: P. Blakiston.'

A Reference Handbook of the Medical s

the Entire Range of Scientific and Prart

lied Science. By Various Autl.

Lithographs and Fine Wood $\mathbf{F}$

Buck, M.D., New Yor'

Co. 1885 .

The Report $c$

for the Year 